\author{
Zh.K. Abeldina*, Zh.E. Moldumarova, G.Sh. Abildina, R.K. Abeldina \\ S.Seifullin Kazakh Agrotechnical University, Nur-Sultan, Kazakhstan \\ (Corresponding author's e-mail: abel-09@yandex.kz) \\ ORCID: 0000-0002-6881-994X \\ ORCID: 0000-0002-0446-5564 \\ ORCID: 0000-0002-0912-2018 \\ ORCID: 0000-0002-2026-8472
}

\title{
Rating as an indicator of the quality of a teacher's professional activity
}

\begin{abstract}
The article examines several aspects of the quality of educational services. The process of providing such services is examined, the problems in the field of teaching physics and mathematics are identified and the ways of problem resolution in the credit learning system are proposed. The introduction of credit learning technology allows for stimulation of students' learning activity and an increase in their motivation and the level of academic mobility. The ways of increasing the motivational activity of the teacher as another key figure in the educational process are identified. The current remuneration system for university teachers in Kazakhstan accounts for work experience and the position held and includes additional payments for an academic degree but does not stimulate teachers for continuous additional training. On the other hand, the salary volume does not contribute to the high social prestige of this profession, which is complex and requires genuine pedagogical skills. The quality of teaching staff is associated with the quality of education acquired by students. In the context of the credit rating system, it is not only students who earn credits, but also teachers who should substantiate and improve their qualifications measured by their rating.
\end{abstract}

Keywords: forms for determining a teacher's rating, teaching quality assessment, credit rating system, quality of education, Education, services, motivation activity, professional level.

\section{Introduction}

The international practice demonstrates that education and science are recognized as the priorities in national development strategies. Meanwhile, society normally does not allocate the amount of resources for higher education sufficient for adequate resolution of the problems of society itself. Experts in the UNESCO suggest that this situation refers to the tendency to perceive educational institutions as business enterprises producing goods and services for sale [1]. This approach is determined by applying the principles of the market to education. These principles are based on freedom of choice and competition, which are not directly applicable to higher education since education is not a branch of the economy, its products are not identical to similar financial categories and the education itself presents a key function of the existence and development of society.

Commercialization in the educational and scientific spheres is caused by changes in the role of the government in these areas. Knowledge becomes a specific product, playing a mutually beneficial role in society's systems of expenditures and consumption. According to World Bank data, education costs relative to GDP in Kazakhstan reach $2.8 \%$, which is lowerthan in Iran (2.9\%) and Russia (3.8\%), but higher than in Afghanistan $(2.5 \%)$.

In the global rating of the level of education expenditures comprised of 153 countries, Kazakhstan takes 127th place. According to the official report of the Ministry of Education and Science of Kazakhstan, over $40 \%$ of 15 -year old students were unable to complete second-level tasks in the Programme for International Student Assessment(PISA) tests, while in other countries of the Organisation for Economic Cooperation and Development (OECD), this indicator fluctuated around $20 \%$ [2]. Despite the overall high level of education in the country, the results of 15-year-old PISA-2012 participants demonstrated the need for education quality improvement. Students from Kazakhstan are on average two years behind children of the same age from the OECD in math and around $45 \%$ of students have not reached literacy threshold, which is a lot higher than average in the OECD (23\%). Compared to the countries with a similar income level, the education sector in Kazakhstan is underfinanced. The lack of resources is reflected on several levels, for example, in low preschool enrollment rates, insufficient payments to teachers, crowded city schools and poorly equipped ungraded schools. At the same time, there are significant opportunities for more efficient resource management in areas such as improving the school network and teaching staff. A gradual increase in government spending is necessary to meet the goals set in the strategic documents for the sector. Additional resources should be 
directed to priority goals, where they can have the most impact — to the sphere of early childhood development and support of weak and dysfunctional schools [3].

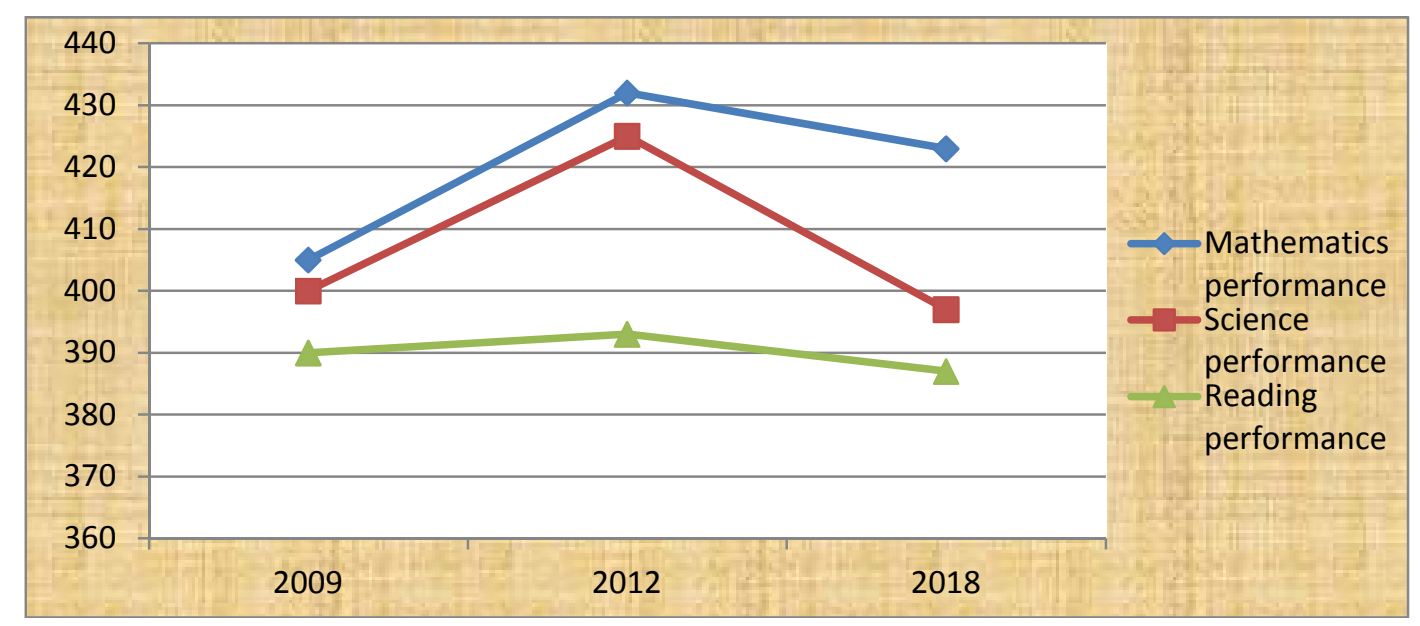

Figure 1. Kazakhstan results according to the data of the PISA in 2009 - 2018 [4]

The results of the PISA and Trends in Mathematics and Science Study (TMSS)in 2009-2018 (Fig. 1) demonstrate that the high school education system in Kazakhstan is effective in providing theoretical knowledge and ensuring memorization, recognition and collection of information by students. However, this education system is relatively ineffective in providing acquisition and practical implementation of higherorder thinking skills, such as practical implementation and logical thinking in mathematics and analysis and evaluation of text in the process of reading. The analysis of the results of Kazakhstan participating in international programs for the assessment of students' educational achievements allows to identify the following major issues:

- Students were able to formulate the task, but could not interpret it correctly. Nine out of ten OECD countries demonstrated the opposite tendency.

- Teachers of secondary schools of the republic provided strong subject knowledge but did not teach students ways to apply it in real-life situations.

The identified issues require a reorientation towards the solution of the main objective of modern education - training people who can adapt to difficult situations quickly and successfully and make right decisions in any, even the most extraordinary situations.

According to the recent research conducted in Kazakhstan and other countries, the intellectual level of students is decreasing above all else due to computer technologies leading to a certain kind of degradation of mental activity while making the search for necessary information easier [5]. This effect is especially present in studying physics and mathematics, as well as natural sciences [6-9].

To date, among all issues associated with changing socio-economic relations, the formation of the market in Kazakhstan and the implementation of all the attributes necessary for a market economy, including competition as the primary factor of self-sufficiency and a guarantee of prosperity, commercialization of education has become the most contentious issue. Until recently, education and commerce have been perceived by society as antagonistic concepts and a strong conviction against market relations in the educational activity has been present in the public mind.

\section{Problem statement and methods.}

The implementation of market formations of the Kazakhstan economy has fundamentally changed the priorities in the higher education system activities. The ultimate goal remains the same - to train highly qualified specialists in demand in the labor market. However, the ways to achieve this goal have changed significantly.

Previously, the attention of teaching staff were focused on the quality of the educational, methodological and scientific organization of the educational process and staffing with highly qualified teachers. Now, teaching staff needs to take care of filling the classrooms with students, i.e. the career guidance activity of teachers intensifies. 
The economic situation affects the forming labor market greatly and reveals the inconsistency between the existing labor structure and the needs of society. The growth of unemployment affects the younger generation, university graduates. Therefore, the goal of teaching staff is not only to provide necessary knowledge but to train a competitive, capable of further training, modern specialist, while taking the demand into account. The three-stage training system (bachelor - master-doctor of philosophy) introduced in Saken Seifullin University in 2004 following the Bologna Agreement using the credit-rating system has provided greater dynamism to the introduction of new educational technologies, the activation of teaching methods and the introduction of elective academic disciplines that bring traditional academic fundamentality closer to the realities of the labor market needs.

The introduction of credit learning technology allowed for stimulation of students' learning activity, an increase in their motivation and the level of academic mobility. What ways are there to increase the motivational activity of the teacher as another key figure of the educational process? After all, the quality of teaching staff is associated with the quality of education acquired by students [10].

Changes in the education system are taking place all over the world in a way that requires wider and more controlled results in relation to educational institutions' objectives, which is also associated with the assessment of student performance and teacher qualifications, as well as greater responsibility of school management. A study [11] analyzed the current policy in the field of education in Brasil, which encourages the measurement of performance of schools and teachers based on students' results in global tests, such as Dendice de Desenvolvimento da Educação Básica (Base Education Development Index, BEDI) and other systems of staff evaluation. Based on the analysis of research on pedagogical work, another question arises: what is teachers' view on the present policy of accountability? It can be concluded that there is a possible correlation between incentives and continuing education policies for basic education teachers, such as career growth, restructuring and bonuses to the salary.

The assessment of the education level of teaching staff is also an important component of auditory learning and professional growth in higher education institutions in China [12-14]. Nowadays, questionnaires are often administered among Chinese students with the goal of teaching quality assessment. At the same time, due to the lack of powerful educational and psychological measures, as well as the theoretical basis for such questionnaires, the question of its validity remains open.

The implementation of the student evaluation of teaching (SET) improved teachers' attitude and trust in students' feedback, which is largely important for the improvement of learning as the main organizational goal of the system [15]. The analysis of SET system monitoring conducted in over 20 educational institutions, which included 2,241 teachers of all degrees, showed that most respondents trusted SET, believed that it accurately reflected their teaching activities and found SET feedback useful. Most participants' concerns were related to students' responsibility: revenge, lack of maturity and negative rating from students with a low level of education. Nonetheless, the resulting index comparing teachers' self-assessments with the rating from students showed that more than a third of the participants rated their quality of education higher than the ratings usually received from their students. This «underrated» group of teachers believed in the negative myths about SET more actively and did not trust it, which suggests a possible self-protective motivation underlying the relationship at departments.

One research [16] examined the aspects of the influence of federal and state policymaking institutions in the United States that seek better differentiation of teachers' work using a more rigorous system of assessment. The aim of the study was to identify the relationship of this policy to such stress factors as financing, enrollment and management. The authors reviewed teacher ratings from 687 areas in Michigan. The results showed that $97 \%$ of the faculty members in Michigan were rated as effective or highly effective. The findings indicate that district-specific stressors, presumably unrelated to the teacher's work, can influence teacher ratings. Reforms of state pedagogical assessment that provide districts with significant freedom of action in developing teacher assessment models might be insufficient for teachers' work differentiation. Researchers from European universities arrived at similar conclusions [17, 18].

The results of an expert survey allowed to determine the main objectives and problems of the development of education in Russia: increasing teachers' salaries, raising their professional level, ensuring the correspondence of the quality of professional educational programs to the requirements of Russian society and the economy [19]. Experts identify the following base issues of the education system: reduced availability, inadequate funding, formalism and bureaucracy, staff quality decline, lack of demand for graduate students. Public-private partnerships are noted as one of the promising areas of development that facilitate the establishment of interaction between employers and universities. Experts emphasize the importance of improving as- 
sessment indicators and creating objective university ratings [20,21]. Similar problems exist in the Kazakh higher education system as well.

However, it is not to be forgotten that the profession of a teacher is associated with a high prevalence of work-related stress. This aspect can lead to permanent problems in the physical and mental health of teachers. It can also negatively affect the health, well-being and educational achievements of children, as well as put a financial burden on the state budget in terms of teaching staff turnover and absence due to illness $[22,23]$.

\section{Results and Discussion.}

Since 2007, the Saken Seifullin University has been approbating forms for determining teachers' rating aimed at evaluating all types of activities performed by a university teacher using a score. Indicators for determining a teacher's rating were developed for this purpose. The indicators included points for academic work, educational and methodologicalal work, research work, research work with students, career guidance and educational work, according to the sections of the individual plan of the teacher approved at the beginning of the school year.

Since 2008, an additional payment for teaching has been introduced; according to the ratings. The payment is calculated ranging from 0 to $30 \%$ of the base salary. Every year, the indicators are discussed by the departments' staff and improved. Proposals submitted by the teaching staff are considered accounting for the activities that were previously not included in the form, but were carried out by teachers, for example, participation in various commissions, publications in highly rated journals included in the Clarivate Analytics, Scopus, Elsevier and Springer Link databases, having quartile, etc.

Further, an additional section is included in the form summing the points taken away from the teacher for various violations that were recorded in the orders or protocols of the relevant commissions. Such forms are submitted and filled in twice a year in accordance with the semester periods, but in the last few years, they have been filled in only once, at the end of the academic year.

It is, therefore, not only students who earn credits, but also the teachers who should substantiate and improve their qualifications, which are measured by the acquired rating verified by the commissions at the faculties and the special rating commission of the university. Table 1 presents the form for determining a teacher's rating with points scored in sections of the teacher's individual work plan.

T a b l e 1

Form for determining a teacher's rating

\begin{tabular}{|c|c|c|c|c|c|c|c|}
\hline \multirow[b]{2}{*}{ № } & \multirow[b]{2}{*}{ Name of group/indicator } & \multirow{2}{*}{$\begin{array}{l}\text { Unit of } \\
\text { measurement }\end{array}$} & \multirow{2}{*}{$\begin{array}{l}\text { Quantityo } \\
\text { f units }\end{array}$} & \multicolumn{3}{|c|}{ Rating score } & \multirow{2}{*}{$\begin{array}{c}\text { Number of } \\
\text { documents } \\
\text { provided }\end{array}$} \\
\hline & & & & Per unit & maximum & Total & \\
\hline 1 & 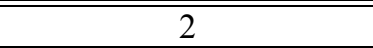 & 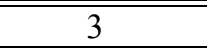 & 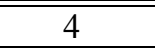 & 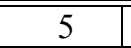 & 6 & 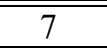 & 8 \\
\hline 1. & \multicolumn{4}{|l|}{ Researchandinnovation } & $\mathbf{1 , 0 3 4 . 0}$ & & \\
\hline 1.1. & \multicolumn{4}{|c|}{ Participationinfundedresearch } & & & \\
\hline 1.1 .1 & \multicolumn{7}{|c|}{ Grant and program-targeted financing: } \\
\hline 1.1 .2 & \multicolumn{7}{|c|}{ Financing from international scientific foundations, foreign organizations: } \\
\hline 1.1 .3 & \multicolumn{7}{|c|}{ Financing through contracts with business entities: } \\
\hline$\ldots$ & \multirow{2}{*}{\multicolumn{7}{|c|}{ Publicationofthemonograph: }} \\
\hline 1.2 . & & & & & & & \\
\hline 1.3. & \multicolumn{7}{|l|}{ Scientificstafftraining: } \\
\hline 1.4. & \multicolumn{7}{|l|}{ Scientificpublications: } \\
\hline 1.4.1. & \multicolumn{7}{|c|}{$\begin{array}{l}\text { in periodicals included in the Clarivate Analytics, Scopus, Elsevier and Springer Link databases, with Q1- } \\
\text { Q4 quartile }\end{array}$} \\
\hline 1.4 .4 & \multicolumn{7}{|c|}{ in periodicals included in Kazakh databases and other databases } \\
\hline$\ldots$ & & & & & & & \\
\hline 1.5. & \multicolumn{7}{|c|}{ Obtaining security documents for intellectual property: } \\
\hline 1.6. & \multicolumn{7}{|c|}{ Introduction of scientific results in production based on the research results } \\
\hline 1.7. & \multicolumn{7}{|c|}{ Additional training and testing of research results: } \\
\hline 2. & \multicolumn{4}{|c|}{ Teachingandeducationalwork } & 362.0 & & \\
\hline 2.1. & \multicolumn{6}{|c|}{$\begin{array}{l}\text { Inclusion of video lectures consistent with the established requirements in the educational } \\
\text { process as a substitute for classroom lectures }\end{array}$} & topic \\
\hline
\end{tabular}


Rating as an indicator of the quality....

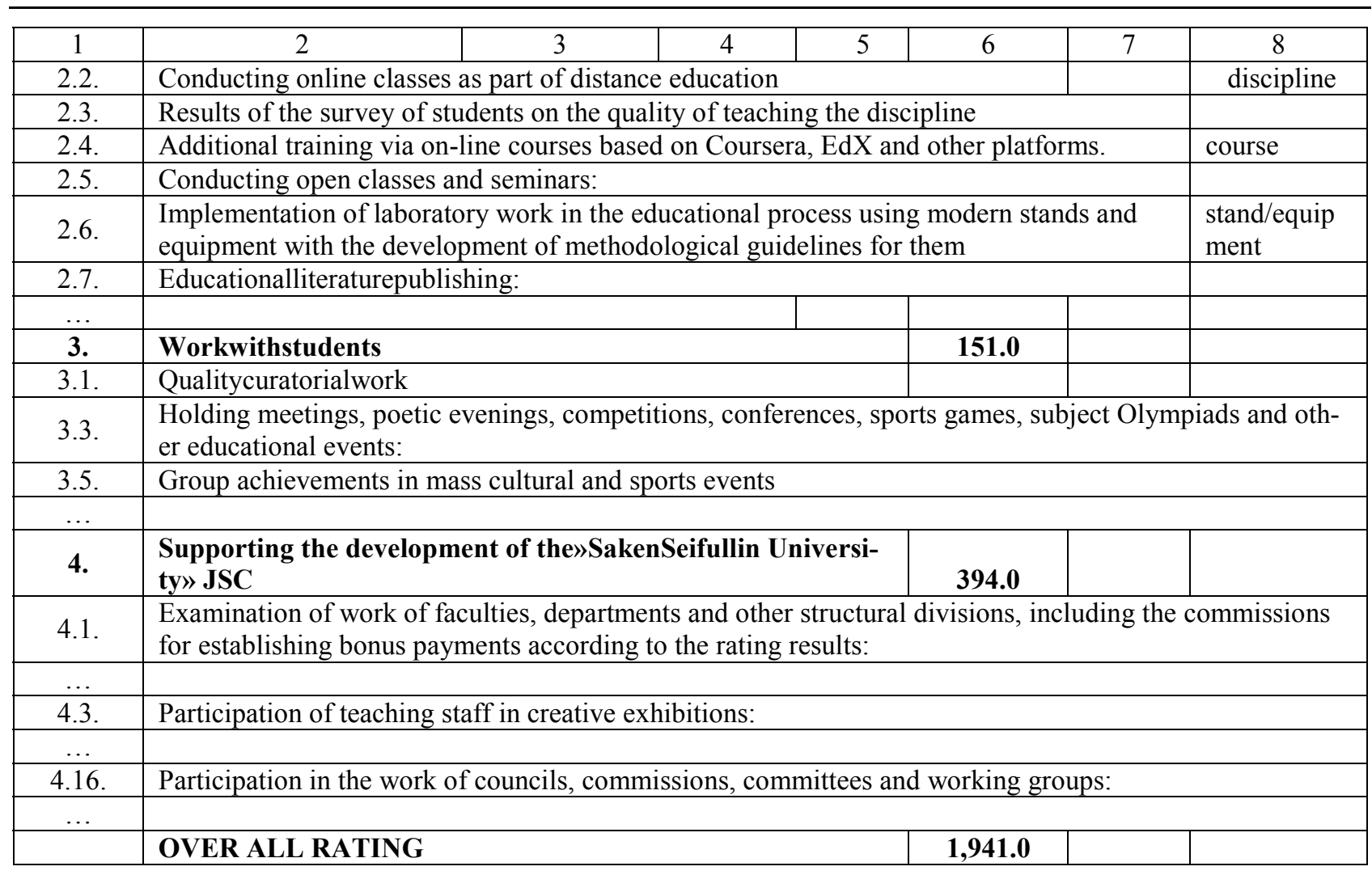

The introduction of the rating system of teaching quality assessment has naturally affected the educational and methodological support of the educational process. The number of textbooks and teaching aids developed by the teaching staff has increased. If previously following the plan for educational and methodological literature (EML) publishing was problematic, now the limitations for the number and types of EML published had to be introduced. The bank of electronic textbooks and electronic educational complexes has been significantly replenished.

The university teachers not only give lectures but perform other various types of work, for example, conduct research in the field of education, scientific research, etc. [24]. The research work in the departments has been revived. It is not only the teaching staff participation in funded research programs that is evaluated, but also the grants of national and international levels that are won and all kinds of scientific research are encouraged. Conducted research contributes greatly to the development of professional level of the employee and their competency in the chosen scientific field since publication of monographs, articles in journals and collections of international, republican and university conferences, as well as reports at conferences, symposiums and other events of various levels, are now taken into account in the rating [25]. A significant contribution to the rating is made by the implementation of research results at an industry or enterprise.

An important part of research work is involving students in it. Advising on research work of the university and school students is taken into account. Training students for conference reports, publishing joint reports and participation in student research competitions are evaluated, as well as receiving awards - diplomas, medals and certificates for scientific contributions. The number of student scientific papers and reports has largely increased since the introduction of teaching staff quality evaluation system.

With the introduction of market relations, career guidance activity began to play an important role in a teacher's work. The number of points scored by the teacher in this section depends on the number of students and undergraduates who chose a university and specialty as a result of the teacher's guidance activity. Moreover, in recent years, payment based on the rating system has become significantly dependent on how actively the employee takes part in career guidance. This is understandable since if students do not choose the university in question, there is no one to teach and the teaching staff is to be significantly reduced. However, the more important reason for the formation of the student population is presented by the so-called educational institution rating determined by the quality of the educational process, the quality of knowledge gained, the competent management and the demand for specialties in the labor market. 
Under the influence of Western technologies, Kazakh universities transfer to the institute of tutors and advisors in accordance with the rating educational technology. However, it is still combined with the curatorial system as the basis of the student's education. This section accounts for the teacher's work as the curator of the group and in other aspects of the educational work of the mentor teacher. In addition, the same section takes other forms of organizational and creative work with students into account.

The rating system of teaching quality assessment penalties following various types of violations recorded in the orders and protocols of the relevant commissions, including the penalties for the inaccuracy of the information provided in the confirmation of a particular type of activity.

\section{Conclusions.}

Is not always possible to assess the quality of a teacher's work by the level of knowledge displayed by their alumni since this criterion integrates the results of multiple teachers' efforts and the input of a specific teacher is rather difficult to isolate. In this case, the teaching quality assessment system is the panacea that allows to evaluate the contribution of a particular teacher and serves as one of the most important tools for education quality management The development and implementation of the teaching quality assessment system in the SakenSeifullin University has allowed for an increase in the quality of the educational services provided, since the university takes the leading position among Kazakh universities, achieving high ratings, and serves for the improvement of wages and management methods.

\section{Acknowledgements.}

The authors express their gratitude to the senior teacher B.E. Alimzhanova and the librarians Z. Orazymbetova and M.Nuralinafor their help in translating and comments during the preparation of the material for publication.

\section{References}

1 Прокопьев В.П. Некоторые аспекты развития рыночных отношений в сфере высшего образования / В.П. Прокопьев // Интеграция образования. - 2000. - С. 35, 36.

2 Байтукенов Т. Жизнь.kz: со статистикой не спорят — её улучшают / Т. Байтукенов // Время. — 2018. — 18 апр.

3 OECD Reviews of School Resources: Kazakhstan [Electronic resource] // 2015 OECD/The World Bank. - Access mode: https://www.oecd-ilibrary.org/education/oecd-reviews-of-school-resources-kazakhstan-2015_9789264245891-en.12.01.2019.

4 Нурбаев Ж. Почему казахстанские школьники провалили международный экзамен PISA? / Ж. Нурбаев [Электронный ресурс]. - Режим доступа: https://cabar.asia/ru/pochemu-kazahstanskie-shkolniki-provalili-mezhdunarodnyjekzamen-pisa 21.05.2020.

5 Мамырханова А.М. Естественнонаучная грамотность обучающихся в средней школе по результатам международных исследований: состояние и пути повышения качества (на примере Казахстана) / А.М. Мамырханова, Г.Б. Есембаева // Междунар. журн. прикл. и фундамент. исслед. - 2015. - № 6 (Ч. 1) - С. 128-131.

6 Strokova T.A. Students' readiness for research activities / T.A. Strokova // Tomsk State University Journal. — 2018. T. 426. - P. 234-237.

7 Kondratska H. Experimental testing of the system of physical education students' professional linguistic culture formation / H. Kondratska, N. Kizlo // Science and Education. - 2017. - T. 8. - P. 133-140.

8 Arun P. Prevalence of specific developmental disorder of scholastic skill in school students in Chandigarh, India / P. Arun, B.S. Chavan, R. Bhargava, A. Sharma, J. Kaur // Indian Journal of Medical Research. — 2013. — Vol. 138. — P. 89-98.

9 Abeldina Zh. Experience in Education Environment Virtualization within the Automated Information System «Platonus» (Kazakhstan)» / Zh. Abeldina, Zh. Moldourova, R.K. Abeldina, Zh.E. Moldoudarova, G. Makysh // IJESE- International Journal of Environmental and Science Education. — 2016. — Vol. 11. — № 18. — P. 12512-12527.

10 Абельдина Ж.К. Об изучении физико-математических дисциплин с применением технологий виртуальной реальности / Ж.К. Абельдина, К.В. Показеев, Ж.К. Молдумарова // Физическое образование в вузах. — 2018. — Т. 24. - № 2. C. $41-53$.

11 Иманбаева А.К. Методика формирования понятия динамического хаоса в вузе / А.К. Иманбаева, Р.Н. Сыздыкова // Вестн. Казах. нац. ун-та. Сер. физ. - 2015. — Т. 54. — № 3. — Р. 102-109.

12 Газалиев А.М. Эффективность рейтинговой системы оценки деятельности преподавателей и подразделений вуза [Электронный ресурс] / А.М. Газалиев, В.В. Егоров, И.В. Брейдо. - Режим доступа: kstu.kz>wpcontent/uploads /2012/ $12 / 5.12 .2018$

13 Augusto M.H. Basic education teachers' valorization and accountability policies: What is new in the PNE? // Cadernos CEDES. - 2015. - Vol. 35. — № 97. — P. 535-552.

14 G. Li. A Multivariate Generalizability Theory Approach to College Students' Evaluation of Teaching / G. Li, G. Hou, X. Wang, D. Yang, H. Jian and W. Wang // Frontiers in Psychology. - 2018. - Vol. 9. - No UNSP 1065. DOI: $10.3389 /$ fpsyg.2018.01065. 
15 Hall T.J. Relationship of Teacher Training and School Characteristics to Middle School State Assessment Results / T.J. Hall, L.K. Hicklin, K.E. French // Journal of Teaching in Physical Education. - 2017. — Vol. 36. — № 4. — P. 467-476.

16 Si L. Performance of Financial Expenditure in China's basic science and math education: Panel Data Analysis Based on CCR Model and BBC Model / L. Si, H. Qiao // Eurasia Journal of Mathematics Science and Technology Education. - 2017. — Vol. 13. — № 8. - P. 5217-5224.

17 Hammer R. Faculty attitudes about student evaluations and their relations to self-image as teacher / R. Hammer, E. Peer, E. Babad // Social Psychology of Education. - 2018. - Vol. 21. - № 3. - P. 517-537.

18 Lenhoff S.W. District stressors and teacher evaluation ratings / S.W. Lenhoff, B. Pogodzinski, D. Mayrowetz et al. // Journal of Educational Administration. - 2018. - Vol. 56. — № 2. - P.146-160. DOI: 10.3389/fpsyg.2018.01065.

19 Rogach O.V., Frolova E.V., Ryabova T.M. Academic Competition: Rating Race / O.V. Rogach, E.V. Frolova, T.M. Ryabova // European Journal Of Contemporary Education. — 2017. — Vol. 6. — № 2. - P. 297-307.

20 Martí M.L. Qualityand efficiency of Spanish Public Universities [Calidad y eficiencia de las Universidades Públicas Españolas] / M.L. Martí, C. Calafat, R. Puertas // Revista de Ciencias Sociales. — 2015. — Vol. 21. — № 2. — P. $234-249$.

21 Aleman de la Garza L. Quality Indicators Proposal For A Massive Open Online Course (Mooc) // 7th International Conference of Education, Research and Innovation (ICERI), Seville, SPAIN, 2014. - P. 5317-5327.

22 Cukusic M. Determinants and Performance Indicators of Higher Education Institutions in Croatia / M. Cukusic, Z. Garaca, M. Jadric // Drustvena Istrazivanja. — 2014. — Vol. 23. — № 2. - P. 233-257.

23 Kalmykov N.N. The Russian higher education: Experts view / N.N. Kalmykov, T.S. Satyr // Sotsiologicheskie Issledovaniya. - 2016. - Vol. 8. - P. 91-97.

24 Naghieh A. Organizational interventions for improving wellbeing and reducing work-related stress in teachers / A. Naghieh, P. Montgomery, C.P. Bonell, M. Thompson, J.L. Aber // Cochrane Database of Systematic Reviews. — 2015. — Vol. 4. CD010306.

25 Shamlikashvili C.A. The effect of the mediator training of teachers of educational institutions on the psychological climate in the team / C.A. Shamlikashvili, S.V. Haritonov, V.P. Grafsky // Psychology and Law. — 2017. — Vol. 7. — № 4. — P. $151-165$.

\author{
Ж.К. Абельдина, Ж.Е. Молдумарова, Г.Ш. Абильдина, Р.К. Абельдина
}

Рейтинг оқытушы қызметінің сапасын бағалау көрсеткіші ретінде

\begin{abstract}
Мақалада көрсетілетін білім беру қызметтері сапасының кейбір аспектілері қарастырылды. Процеске талдау жүргізілді, физика-математикалық пәндерді оқыту саласындағы проблемалар анықталды, студенттерге білім берудің кредиттік жүйесінің жұмыс істеуі жағдайында проблемаларды шешу жолдары ұсынылған. Кредиттік оқыту технологиясын енгізу студенттердің танымдық іс-әрекетін ынталандыруға, мотивациясын күшейтуге және олардың академиялық ұтқырлығын арттыруға мүмкіндік берді. Білім беру процесінің тағы бір негізгі тұлғасы - оқытушының мотивациялық белсенділігін қалай күшейту керектігі анықталды. Сонымен қатар, қазіргі уақытта Қазақстанда ЖОО оқытушыларының жұмыс өтілін, атқаратын лауазымын, ғылыми дәрежесі үшін төленетін қосымша ақыны есепке алуға негізделген еңбек ақы төлеу жүйесі оқытушыларды өз біліктілігін үнемі арттырып отыруға ынталандырмайды. Екінші жағынан, жалақы мөлшері осы күрделі және шынайы педагогикалық шеберлікті қажет ететін кәсіптің қоғамдағы жоғары беделіне ықпал етпейді. Өйткені, профессорлық-оқытушылар құрамының сапасы - бұл білім алушылардың алған білімінің сапасы. Кредиттік-рейтингтік жүйе жағдайында студенттер ғана кредит жинамайды, сонымен қатар педагогтар да өздерінің жинаған рейтингімен бағаланатын біліктіліктерін дәлелдеп және жетілдіруі керек.
\end{abstract}

Кілт сөздер: оқытушының рейтингін анықтауға арналған сауалнамалар, оқыту сапасын бағалау, кредиттік-рейтингтік жүйе, оқыту сапасы, білім беру, қызмет көрсету, мотивациялық іс әрекет, кәсіби деңгей.

\title{
Ж.К. Абельдина, Ж.Е. Молдумарова, Г.Ш. Абильдина, Р.К. Абельдина
}

\section{Рейтинг как показатель оценки качества деятельности преподавателя}

В статье рассмотрены некоторые аспекты качества предоставляемых образовательных услуг. Проведен анализ процесса, выявлены проблемы в области преподавания физико-математических дисциплин, предложены пути решения проблем в условиях функционирования кредитной системы обучения студентов. Введение кредитной технологии обучения позволило стимулировать познавательную деятельность студентов, усилить мотивацию и повысить их академическую мобильность. Выявлено, каким образом можно усилить мотивационную деятельность другой ключевой фигуры образовательного процесса - преподавателя. Между тем, существующая в настоящий момент в Казахстане система оплаты труда преподавателей вузов, основанная на учёте стажа работы, занимаемой должности, с доплатами за ученую степень, не стимулирует преподавателей к постоянному повышению своей квалификации. С другой стороны, величина оклада не способствует высокому престижу в обществе этой 
сложной и требующей подлинного педагогического мастерства профессии. Ведь качество профессорско-преподавательского состава - это и качество полученных учащимися знаний. В условиях кредитно-рейтинговой системы не только студенты зарабатывают кредиты, но и педагоги должны доказывать и повышать свою квалификацию, которая оценивается набранным рейтингом.

Ключевые слова: анкеты для определения рейтинга преподавателя, оценка качества преподавания, кредитно-рейтинговая система, качество обучения, образование, услуги, мотивационная деятельность, профессиональный уровень.

\section{References}

1 Prokopev, V.P. (2000). Nekotorye aspekty razvitiia rynochnykh otnoshenii v sfere vyssheho obrazovaniia [Some aspectsof the market relations development in higher education]. Intehratsiia obrazovaniia - Interaction of education, 35, 36 [in Russian].

2 Baitukenov, T. (2018). Zhizn.kz: so statistikoi ne sporiat - ee uluchshaiut [Life.kz: the statistics are not to argue with but to improve]. Vremia Time, April, 18 [in Russian].

3 OECD Reviews of School Resources: Kazakhstan//2015 OECD/The World Bank. oecd-ilibrary.org. Retrieved from https://www.oecd-ilibrary.org/education/oecd-reviews-of-school-resources-kazakhstan-2015_9789264245891-en.12.01.2019.

4 Nurbaev, Zh. Pochemu kazakhstanskie shkolniki provalili mezhdunarodnyi ekzamen PISA? [Why Did Kazakhstan Fail The International PISA Assessment?]. cabar.asia/ru. Retrieved from https://cabar.asia/ru/pochemu-kazahstanskie-shkolniki-provalilimezhdunarodnyj-ekzamen-pisa21.05.2020 [in Russian].

5 Mamyrkhanova, A.M., \& Esembaeva, G.B. (2015). Estestvennonauchnaia hramotnost obuchaiushchikhsia v srednei shkole po rezultatam mezhdunarodnykh issledovanii: sostoianie i puti povysheniia kachestva (na primere Kazakhstana) [Natural science literacy of high school students in international research: current status and ways of quality improvement (on the example of Kazakhstan)]. Mezhdunarodnyi zhurnal prikladnykh i fundamentalnykh issledovanii, No. 6 (Part 1), 128-131 [in Russian].

6 Strokova, T.A. (2018). Students' readiness for research activities. Tomsk State University Journal, Vol. 426, $234-237$.

7 Kondratska H., \& Kizlo N. (2017). Experimental testing of the system of physical education students' professional linguistic culture formation. Science and Education, Vol. 8, 133-140.

8 Arun, P., Chavan, B.S., Bhargava, R., Sharma, A., \& Kaur, J. (2013). Prevalence of specific developmental disorder of scholastic skill in school students in Chandigarh, India. Indian Journal of Medical Research, Vol. 138, 89-98.

9 Abeldina, Zh., Moldourova, Zh., Abeldina, R.K., Moldoudarova, Zh.E., \& Makysh, G. (2016). Experience in Education Environment Virtualization within the Automated Information System «Platonus» (Kazakhstan)». IJESE- International Journal of Environmental and Science Education, Vol. 11, No 18, 12512-12527.

10 Abeldina, Zh.K., Pokazeev, K.V., Moldumarova, Zh.K., \& Moldumarova, Zh.E. (2018). Ob izuchenii fizikomatematicheskikh distsiplin s primeneniem tekhnolohii virtualnoi realnosti [On studyingphysics and mathematics using virtual reality technologies]. Fizicheskoe obrazovanie v vuzakh, Vol. 24, No. 2, 41-53 [in Russian].

11 Imanbaeva, A.K., \& Syzdykova, R.N. (2015). Metodika formirovaniia poniatiia dinamicheskoho khaosa v vuze [Method for the formation of the dynamic chaos concept in a university]. Vestnik Kazakhskoho natsionalnoho universiteta. Seriia fizicheskaia KazNU journal. Seriia Fizicheskaia, Vol. 54, № 3, 102-109 [in Russian].

12 Gazaliev, A.M., Egorov, V.V., Breido, I.V. Effektivnost reitinhovoi sistemy otsenki deiatelnosti prepodavatelei i podrazdelenii vuza [The effectiveness of the rating system for assessing the activities of teachers and departments of the university]. $k s t u . k z$. Retrieved from kstu.kz>wpcontent/uploads /2012/ 12/5.12.2018 [in Russian].

13 Augusto, M.H. (2015). Basic education teachers' valorization and accountability policies: What is new in the PNE? Cadernos CEDES, Vol. 35, No 97, 535-552.

14 G. Li, G. Hou, X. Wang, D. Yang, H. Jian \& W. Wang, (2018). A Multivariate Generalizability Theory Approach to College Student evaluation of teaching. Frontiers in Psychology, Vol. 9, No UNSP 1065. DOI: 10.3389/fpsyg.2018.01065.

15 Hall, T. J., Hicklin, L. K., \& French, K.E. (2017). Relationship of Teacher Training and School Characteristics to Middle School State Assessment Results. Journal of Teaching in Physical Education, Vol. 36, No 4, 467-476.

$16 \mathrm{Si}$, L., \& Qiao, H. (2017). Performance of Financial Expenditure in China's basic science and math education: Panel Data Analysis Based on CCR Model and BBC Model. Eurasia Journal of Mathematics Science and Technology Education, Vol. 13, No 8, $5217-5224$

17 Hammer, R., Peer, E., \& Babad, E. (2018). Faculty attitudes about student evaluations and their relations to self-image as teacher. Social Psychology of Education, Vol. 21, 3, 517-537.

18 Lenhoff, S.W., Pogodzinski, B. \& Mayrowetz, D. et al. (2018). District stressors and teacher evaluation ratings. Journal of Educational Administration, Vol. 56, No 2, 146-160. DOI: 10.3389/fpsyg.2018.01065.

19 Rogach, O.V., Frolova, E.V., \& Ryabova, T.M. (2017). Academic Competition: Rating Race. European Journal Of Contemporary Education, Vol. 6, No 2, 297-307.

20 Martí, M.L., \& Calafat, C. (2015). Puertas R.Qualityand efficiency of Spanish Public Universities [Calidad y eficiencia de las UniversidadesPúblicasEspañolas]. Revista de CienciasSociales, Vol. 21, No 2, 234-249.

21 Aleman de la Garza, L. Quality Indicators Proposal For A Massive Open Online Course (Mooc). 7th International Conference of Education, Research and Innovation (ICERI), Seville, SPAIN, 2014. - P. 5317-5327.

22 Cukusic, M., Garaca, Z., \& Jadric, M. (2014). Determinants and Performance Indicators of Higher Education Institutions in Croatia. Drustvena Istrazivanja, Vol. 23, No 2, 233-257.

23 Kalmykov, N.N., \& Satyr, T.S. (2016). The Russian higher education: Experts view. Sotsiolohicheskie issledovaniia, Vol. 8, $91-97$ 
24 Naghieh, A., Montgomery, P., Bonell, C.P., Thompson, M., \& Aber, J.L. (2015). Organizational interventions for improving wellbeing and reducing work-related stress in teachers. Cochrane Database of Systematic Reviews, Vol. 4. CD010306.

25 Shamlikashvili, C.A., Haritonov, S.V., \& Grafsky, V.P. (2017). The effect of the mediator training of teachers of educational institutions on the psychological climate in the team. Psychology and Law, Vol. 7, No 4, 151-165. 